\title{
Long-term warming does not affect soil ecoenzyme activity and original microbial nutrient limitation on the Qinghai- Tibet Plateau
}

\author{
Yuanze $\mathrm{Li}^{1{ }^{1},}$, Huakun Zhou, ${ }^{2,3,}$, Wenjing Chen ${ }^{1}$, Yang $\mathrm{Wu}^{1}$, LeiLei Qiao ${ }^{4}$, ZiRan Yan ${ }^{5}$, GuoBin Liu ${ }^{1,4}$, \\ Sha Xue ${ }^{1,4, *}$
}

1 State Key Laboratory of Soil Erosion and Dryland Farming on the Loess Plateau, Institute of Soil and Water Conservation, Northwest A\&F University, Yangling 712100, China

2 Qinghai Provincial Key Laboratory of Restoration Ecology in Cold Regions, Northwest Institute of Plateau Biology, Chinese Academy of Sciences, Xining 810000, China

3 State Key Laboratory of Plateau Ecology and Agriculture, Qinghai University, Xining 810000, China

4 Institute of Soil and Water Conservation, Chinese Academy of Sciences and Ministry Water Resources, Yangling 712100, China

5 College of Natural Resources and Environment, Northwest A\&F University, Yangling 712100, China

H I G H L I G H T S

- No notable effect from long-term warming on activity of nutrient-acquiring enzymes.

- Long-term warming does not notably affect enzymatic stoichiometry.

- Significant and positive correlation between ecoenzyme activity and soil nutrients, microbial biomass.

- Phosphorus limitation was found for all soil microbes at different depths.

\section{ARTICLE INFO}

Article history:

Received April 12, 2021

Revised June 8, 2021

Accepted June 13, 2021

Keywords:

Global warming

Ecoenzymatic stoichiometry

Microbial nutrient limitation

Thermal acclimation

Qinghai-Tibet Plateau
GRAPHICAL ABSTRACT

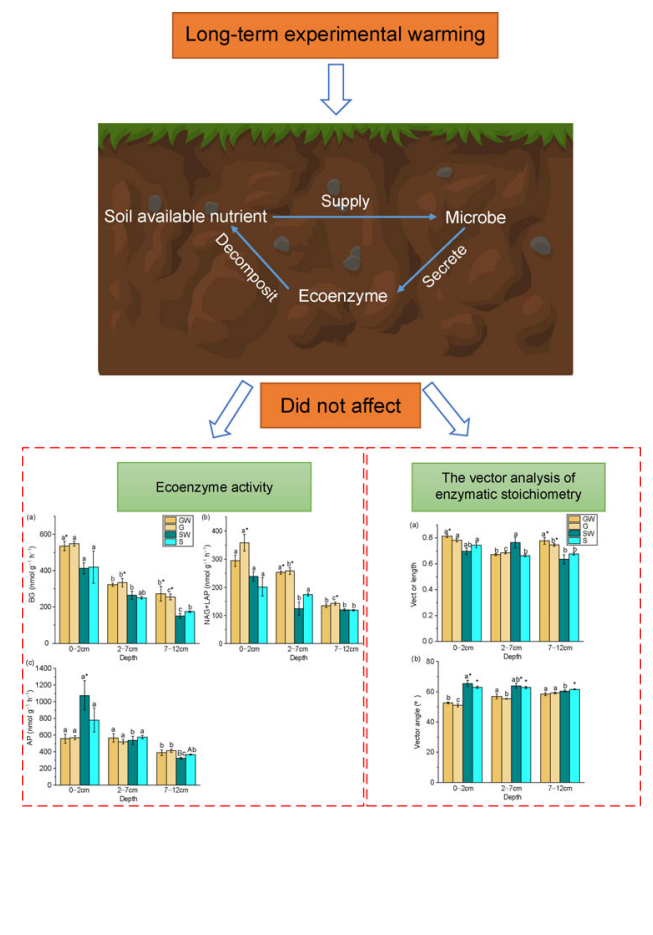

* Corresponding author

E-mail address: xuesha100@163.com (S. Xue)

†These authors contributed equally to this work. 
Microbes play an important role in the carbon cycle and nutrient flow of the soil ecosystem. However, the response of microbial activities to long-term warming over decades is poorly understood. To determine how warming changes ecoenzyme activity and microbial nutrient limitation, we conducted a long-term, 21 years, experiment, on the Qinghai-Tibet Plateau. We selected typical grass- and shrub-covered plots, used fiberglass open-top chambers (OTCs) to raise the temperature, conducted soil sampling at different depths, studied the response of nutrient-acquiring enzyme activity and stoichiometry, and conducted vector analysis of stoichiometry. Our results showed that long-term warming did not have a notable effect on the activity of nutrient-acquiring enzymes or enzymatic stoichiometry. However, Spearman correlation analysis indicated a significant and positive correlation between ecoenzyme activity and the available nutrients and microbial biomass in soil. Vector analysis of stoichiometry showed phosphorus limitation for all soil microbes at different depths, regardless of whether the soil experienced warming. These changes in enzymatic stoichiometry and vector analysis suggested that microbial nutrient limitation was not alleviated substantially by long-term warming, and warming did not considerably affect the stratification of microbial nutrient limitation. Our research has also shown that long-term warming does not significantly change soil ecoenzyme activity and original microbial nutrient limitation at different soil depths within the OTUs' impact range. These results could help improve understanding of microbial thermal acclimation and response to future long-term global warming

\section{Introduction}

Global warming is a pressing ecological and environmental concern. Human-activity-induced warming in 2017 amounted to approximately $1^{\circ} \mathrm{C}$ above pre-industrial levels (IPCC, 2018). Studies have shown that such temperature changes profoundly affect the carbon cycle and nutrient flow process in terrestrial ecosystems, as these processes are driven mainly by microbial decomposition of soil organic matter, and in this process, temperature affects the microbial community structure and activity (Rustad et al., 2001; Zhang et al., 2015; Xu and Yuan, 2017; Zi et al., 2018). Meanwhile, the temperature change will affect soil property and microbial substrate availability which requires that microbes produce ecoenzymes in response to resource availability and to maintain stoichiometry (Cleveland and Liptzin, 2007; Sinsabaugh et al., 2008; Machmuller et al., 2016). The restriction of ecosystem nutrients, such as carbon (C), nitrogen $(\mathrm{N})$, and phosphorus $(P)$ on microbial activities during environmental changes is called microbial nutrient limitation (Chen et al., 2019). As soil microbes play an important role in ecosystem processes, determining whether the microbial nutrient limitation is affected by long-term warming is crucial in illustrating the future energy and nutrient flow mechanism of the ecosystem in the context of changes brought about by global warming. Further, such information could improve understanding of the consequences of such warming.

Most soil ecoenzymes are microbial metabolites, and they play a key role in regulating the circulation and fixation of soil nutrients, and their activity reflects the response of the microbes to their metabolic resource requirements (Barta et al., 2014; Veres et al., 2015). Therefore, soil ecoenzymatic stoichiometry is considered a useful indicator of soil microbial resource limitation (Caldwell, 2005; Sinsabaugh et al., 2009; Sinsabaugh and Shah, 2012). Moorhead et al. (2013, 2016) proposed employing vector analysis of enzyme stoichiometry to visualize microbial nutrient limitation. Studies employing such methods have been conducted on the effect of warming on microbial resource limitations. However, most of these pertained only to short-term experimental warming. Gong et al. (2019) found that the combined effects of warming and $N$ addition could change $\mathrm{C}, \mathrm{N}, \mathrm{P}$ cycling by affecting soil and SMB C:N:P ratios, and then ease $\mathrm{N}$-limitation but aggravate P-limitation. Zheng et al. (2020) found that short-term warming would change the microbial $C$ and $P$ demand and enhance the microbial phosphorus limitation, but the bacterial diversity and community structure showed temperature adaptability to soil warming, while Machmuller et al. (2016) demonstrated no response of enzyme ratios to warming, other factors in soil could regulate temperature sensitivity of microbial secretion activities to temperature changes. These studies have shown that short-term warming has a significant effect on soil microbial resource limitation, but also that the microbial community showed temperature adaptability to soil warming. The temperature adaptability of microbial communities after long-term warming was found that is different from that after short-term warming. Schindlbacher and coworkers (2015) showed that enzyme activity increased after long-term temperature rise whereas Xiao et al. (2018) found that warming tended to stimulate hydrolytic enzymes, although this effect was not substantial.

From these studies, it is apparent that short-term warming changed soil microbial resource limitation. However, the temperature adaptability of the microbial community to longterm soil warming remains unclear. We could not confirm whether long-term warming would continue to enhance the original microbial nutrient limitation, which had been strengthened by short-term warming, or alleviate this limitation by influencing enzyme activity. Further, compared with the stress reaction of microbes under short-term warming, microbial response to long-term warming is considered more reliable for predicting future trends in the ecosystem.

Because of the influence of soil depth, many soil properties 
generally show stratification at different depths and consequently, the soil stratification ratio (SR) is used widely as a key indicator of soil conditions (Yu et al., 2020). Temperature changes affect the surface soil first and then gradually affect the deeper soil, although the effect of warming on the soil is weakened with soil depth because of the soil buffer and barrier effect (Fierer et al., 2003; Bai et al., 2019). Warming change the substrate utilization rate of different soil layers, and then indirectly affect the ecological enzyme activities of each layer (Deltedesco et al., 2020). Recent studies have shown that the effect of temperature on enzymes showed a stratification phenomenon, that is, the response of enzyme activity of the topsoil to warming differed from that of the lower soil (Zhou et al., 2013; Zheng et al., 2019). Accordingly, stratification of soil properties and soil ecoenzymes also leads to stratification of soil microbial activity and limitations.

The Qinghai-Tibet Plateau, with high altitude and cold climate, is the largest and highest single geomorphic unit in the world. Because of its unique geographical location and resource conditions, this plateau is more sensitive to global climate change than many other regions (Rui et al., 2012). Exploring the soil enzyme activity and microbial nutrient limitation in this area could provide a reference for ecosystem processes under climate warming. We selected typical grassand shrub-covered plots on the plateau for experimental warming treatment lasting 21 years. At the end of that time, we obtained soil samples from different depths to determine the effects of long-term warming on ecoenzyme activity and microbial nutrient limitation. We hypothesized that 1) after long-term warming, the temperature changes would affect the soil properties and utilization of microbial substrates, soil enzyme activity would be significantly increased, and the microbial nutrient limitation would continue to enhance the original nutrient limitation with the increase of enzyme activity 2 ) the response of microbial nutrient limitation of surface soil to long-term warming would be greater, and there would be obvious stratification between different soil layers.

\section{Materials and methods}

\subsection{Experimental site}

The study site was located at the National Wildlife Observation and Research Station of the Haibei Alpine Grassland Ecosystem in Qinghai (referred to as the Haibei Station). The geographical range of the Haibei Station is latitude $37^{\circ} 29$ $37^{\circ} 45 \mathrm{~N}$, longitude $101^{\circ} 12-101^{\circ} 23 \mathrm{E}$. The mean elevation of the valley bottom is $3200 \mathrm{~m}$. The mean annual temperature is $-1.7^{\circ} \mathrm{C}$, ranging from $-15.2^{\circ} \mathrm{C}$ in January to $9.9^{\circ} \mathrm{C}$ in July. The mean annual precipitation is $561 \mathrm{~mm}$, mainly distributed during summer. The growing season generally lasts from May to September. The soil type is Mollic-Cryic Cambisols. The vegetative communities are mainly alpine meadow and alpine shrub.

\subsection{Experiment design and sampling}

In 1997, grassland dominated by Kobresia humilis and shrubland dominated by Hamamelis molis were selected as the study sites. A fence was erected to protect the two $30 \mathrm{~m} \times$ $30 \mathrm{~m}$ field sites from grazing animals. Six plots were built at each site. The total area of each plot was $1.77 \mathrm{~m}^{2}$, with a $2 \mathrm{~m}$ buffer zone between each plot. On each plot, fiberglass opentop chambers (OTCs) was used to raise the temperature, with the OTCs remaining on the plots year-round. The mean daily air temperature (at a height of $10 \mathrm{~cm}$ ) and the mean underground soil temperature (at a depth of $0.12 \mathrm{~m}$ ) were elevated to $1.0-2.0^{\circ} \mathrm{C}$ and $0.3-1.9^{\circ} \mathrm{C}$, respectively, during the growing season (Zhang et al., 2017). A control plot (unwarmed) was set next to each OTC plot for comparison with the warming treatment. Accordingly, there was a total of four treatment plots, namely grassland warmed plots (GW), grassland unwarmed plots (G), shrub warmed plots (SW), and shrub unwarmed plots (S), and each treatment has 6 experimental replicates.

Soil samples were collected from two sites in August 2018. The stratified sampling was conducted within a depth of $12 \mathrm{~cm}$ in the soil based on the impact range of the OTCs and measured soil temperature changes in the plots. In each plot, soil cores were collected using a soil drilling sampler $(2 \mathrm{~cm}$ diameter) from the $0-2 \mathrm{~cm}, 2-7 \mathrm{~cm}$, and 7-12 cm layers, with six soil cores pooled to make one sample. These three depths were chosen to ensure that the underlying soil can also accept the warming effect and only soil samples within a $12 \mathrm{~cm}$ depth were collected. All samples were sieved through a 2-mm mesh after stones and roots had been removed. After returning to the laboratory, the samples were stored at $4^{\circ} \mathrm{C}$ for measuring available soil nutrients, microbial biomass, and enzymatic activity.

While collecting soil samples, a small grid of $0.25 \mathrm{~m} \times 0.25$ $\mathrm{m}$ was established inside and outside each treatment plot at the same time, and vegetation characteristics were measured in each grid, measuring relative coverage, plant height, and abundance in each square. The above-ground parts of all plants in each $0.25 \mathrm{~m} \times 0.25 \mathrm{~m}$ square were collected by trimming, and dried in an oven at $65^{\circ} \mathrm{C}$ for $48 \mathrm{~h}$ to calculate the above-ground biomass.

\subsection{Soil property measurements}

$100 \mathrm{~g}$ samples of soil were heated to dry at $105^{\circ} \mathrm{C}$ to constant weight, and soil moisture content was measured by weighing. Soil dissolved organic matter components were modified by Kalbitz et al. (2003) and Liu et al. (2019). The fresh soil samples were weighed to $40 \mathrm{~g}$, added $120 \mathrm{~mL}$ distilled water, and then shaken for $30 \mathrm{~min}$ at $25^{\circ} \mathrm{C}$. After these, the samples were centrifuged at high speed $\left(5000 \mathrm{r} \mathrm{min}^{-1}\right)$ for $10 \mathrm{~min}$, filtered the supernatant with a $0.45 \mu \mathrm{m}$ filter membrane. And then the supernatants were frozen to determine the soil dissolved organic matter component. Dissolved organic 
carbon was measured by TOC analyzer (liquid TOC II, elementar, Germany); the total water-soluble nitrogen in the soil was measured by basic potassium persulfate digestionUV spectrophotometry, and water-soluble nitrate nitrogen was measured by ultraviolet colorimetry. The water-soluble ammonium nitrogen was measured by the continuous flow analyzer, and it was determined that soil dissolved organic nitrogen was the difference between water-soluble total nitrogen, and nitrate-nitrogen, ammonium nitrogen (The DON was calculated as $\mathrm{TDN}-\mathrm{NH}_{4}{ }^{+}-\mathrm{NO}_{3}{ }^{-}$). Soil available phosphorus was determined by the Olsen method (Cui et al., 2018). At $25^{\circ} \mathrm{C}, 2.5 \mathrm{~g}$ of air-dried soil and a spoonful of phosphorus-free activated carbon were mixed with $50 \mathrm{~mL}$ $0.5 \mathrm{M} \mathrm{NaHCO}_{3}(\mathrm{pH}=8.5)$ for $30 \mathrm{~min}$, filtered, and $5 \mathrm{~mL}$ of molybdenum antimony reagent was added to $10 \mathrm{~mL}$ of filtrate and this was diluted to $25 \mathrm{~mL}$ with water. The solution was measured with an ultraviolet spectrophotometer at $700 \mathrm{~nm}$ (Shimadzu UV1800).

The microbial biomass of $\mathrm{C}, \mathrm{N}$, and $\mathrm{P}$ (SMBC, SMBN, SMBP were analyzed by chloroform fumigation extraction (Brookes et al., 1985; Vance et al., 1987). Fresh soil samples were fumigated with $\mathrm{CHCl}_{3}$ for $24 \mathrm{~h}$. The fumigated samples were divided into two parts, one was extracted with $\mathrm{K}_{2} \mathrm{SO}_{4}$ to measure SMBC and SMBN, and the other was extracted with $0.5 \mathrm{~mol} \mathrm{~L}^{-1} \mathrm{NaHCO}_{3}(\mathrm{pH}=8.5)$ to measure SMBP. Then take fresh soil samples without fumigation treatment and extract them with $\mathrm{K}_{2} \mathrm{SO}_{4}$ and $\mathrm{NaHCO}_{3}$. The carbon content was determined by a TOC analyzer, the nitrogen content was determined by alkaline potassium persulfate digestion-ultraviolet spectrophotometry, and the phosphorus content was determined by the Olsen method. The final result is the fumigation part minus the non-fumigation part. And the conversion factors were $0.45,0.54$, and 0.40 for SMBC, SMBN and SMBP, respectively.

\subsection{Ecoenzyme activity analyses}

Through previous research, we identified various ecoenzymes as valuable indicators in exploring microbial nutrient requirements (Sinsabaugh et al., 2009; Sinsabaugh and Shah, 2012; Sinsabaugh et al., 2012; Waring et al., 2014; Tapia-Torres et al., 2015; Cui et al., 2018; Zhang et al., 2019; Wang et al., 2020). These are $\beta-1,4-$ glucosidase (BG) as an indicator of carbon demand; $\beta-1,4-N$-acetylglucosaminidase (NAG) and leucine aminopeptidase (LAP) as indicators of nitrogen demand; and alkaline phosphatase (AP) as indica- tors of phosphorus demand (Table 1). The potential activities of these enzymes were measured using modified standard fluorescence techniques (Saiya-Cork et al., 2002; Steinweg et al., 2012). 96-well microplates were used for detection, with eight replicate microwells per analysis. The analysis included sample reaction wells $(150 \mu \mathrm{L}$ sample suspension $+50 \mu \mathrm{L}$ fluorescent substrate), blank microwells (150 $\mu \mathrm{L}$ sample suspension $+50 \mu \mathrm{L}$ Tris buffer), negative control microwells (150 $\mu \mathrm{L}$ Tris buffer $+50 \mu \mathrm{L}$ fluorescent bottom substance), quenched standard microwells (150 $\mu \mathrm{L}$ sample suspension + $50 \mu \mathrm{L}$ standard solution), and reference standard microwells (150 $\mu \mathrm{L}$ Tris buffer $+50 \mu \mathrm{L}$ standard solution). The $\mathrm{pH}$ of the Tris buffer was the same as that of the soil. After loading the microplate, the mixture was shaken and incubated in a $25^{\circ} \mathrm{C}$ incubator for $0.5 \mathrm{~h}(\mathrm{AP}), 2 \mathrm{~h}$ (NAG and LAP), or $4 \mathrm{~h}(\mathrm{BG})$ according to the incubation time required for different ecoenzymes. A microplate reader was used to determine the amount of fluorescence (excitation wavelength of $365 \mathrm{~nm}$ and emission spectrum of $450 \mathrm{~nm}$ ). After adjusting the negative control and quenching standard, enzyme activity was measured in units of $\mathrm{nmol} \mathrm{g} \mathrm{g}^{-1} \mathrm{~h}^{-1}$.

\subsection{Indicators of microbial nutrient limitation}

Two indicators in our results indicated the limits of microbial nutrients. The first is the ratio of enzyme activity (e.g., BG/ $(L A P+N A G))$. The other is the vector analysis of enzymatic stoichiometry (Moorhead et al., 2013; Moorhead et al., 2016). Vector length (unitless) and vector angle $\left(^{\circ}\right)$ were calculated using proportions (e.g., BG/(BG + AP)), because Moorhead et al. (2016) found that expressing relative activities as proportions instead of ratios (e.g., BG/AP) eliminated undefined values resulting from a zero in the denominator or in a logarithmic transformation.

Vector length

$$
=\sqrt{\left(B G /(B G+N A G+L A P)^{2}+(B G /(B G+A P))^{2}\right.}
$$

$$
\begin{aligned}
\text { Vector angle }= & \operatorname{Degrees}(\operatorname{ATAN} 2((B G /(B G+A P)),(B G /(B G \\
& +N A G+L A P)))
\end{aligned}
$$

A relatively long vector length indicated greater C-limitation; the vector angles $<45^{\circ}$ and $>45^{\circ}$ indicated $\mathrm{N}$ - and $\mathrm{P}$-limitation, respectively (Moorhead et al., 2013; Moorhead et al., 2016). When vector angle $<45^{\circ}$, a smaller angle indicated stronger $\mathrm{N}$-limitation of microbial nutrients. Similarly, when vector angle

Table 1 Enzyme introduction of this study.

\begin{tabular}{llll}
\hline Group & Enzyme name & Abbrev. & Function \\
\hline C-acquiring enzyme & $\beta-1$, 4-glucosidase & BG & Hydrolysis of cellobioside \\
N-acquiring enzymes & $\beta$-N-acetylglucosaminidase & NAG & Hydrolysis of chitin \\
& Leucine aminopeptidase & LAP & Hydrolysis of protein \\
\hline
\end{tabular}


$>45^{\circ}$, a greater angle indicated stronger P-limitation of microbial nutrients.

\subsection{Calculation and statistical analysis}

The SR values were calculated from enzymatic stoichiometry and the vector analysis of stoichiometry. SR1 was the data of 0-2 cm:2-7 cm and SR2 was 0-2 cm:7-12 cm (Franzluebbers, 2002).

ANOVA was used to determine differences in measurement variables of soil samples at different depths under the same treatment. The $t$-test was used to detect differences in the measured variables of differently treated samples between the same depth and between different vegetation plots under the same depths and treatment. These variables included calculations of the available nutrients, microbial biomass, enzyme activity, stoichiometry, vector analysis of enzymatic stoichiometry, and SRs. When the effect was significant, the least significant difference (LSD) test was used for multiple comparisons. All reported significant differences were $p<0.05$. Three-way ANOVA was used to test vegetation, warming, soil depth, and their interaction with the measured variables. The individual contributions of the independent factors of vegetation, warming, soil depth and their interactive effects on various parameters were calculated by dividing the sum of squares of the factors or their interactions by the total sum of squares and multiplying by 100 to obtain the percentage contribution (Xue et al., 2017). Spearman coefficients were used to evaluate the relationship between soil properties and the indicators of microbial nutrient limitation. The above statistical analysis was performed using SPSS 23 (SPSS Inc., Chicago, Illinois, USA) and R v.4.0.2 software ( $R$ Development Core Team, 2019). Origin 2019b (Origin Laboratory Corporation, Northampton, MA, USA) was used for all histogram plotting drawings.

\section{Results}

\subsection{Soil available nutrients and their stoichiometry}

In the grassland plots, experimental warming significantly increased the DOC contents and DOC:DON ratio, DOC:SAP ratio at $0-2 \mathrm{~cm}$ depth but, at $7-12 \mathrm{~cm}$, significantly reduced the DOC content and DOC:DON compared to that of the unwarmed plots (Fig. 1). In the shrubland plots, long-term warming significantly increased the SAP content at 2-7 cm depth, leading to a significant decrease in DON: SAP ratio at this depth after the warming treatment. The DOC:SAP ratio in shrubland significantly decreased at all depths during longterm warming (Fig. 1). Compared with differing vegetation and warming, it was found soil depth was the most significant environmental factor affecting the available nutrients and their stoichiometry. Further, warming significantly affected only on SAP and the stoichiometry related to SAP (Table 2).

\subsection{Soil microbial biomass and stoichiometry}

Long-term warming decreased the SMBC content significantly at $7-12 \mathrm{~cm}$ in the grassland but did not have a significant effect on the other microbial biomass. With regard to the stoichiometry of microbial biomass in grassland, SMBC: SMBN and SMBC:SMBP showed a significant increase at 2-7 cm depth but a significant decrease at 7-12 cm depth (Fig. 2). In the shrubland, despite experimental warming resulting in a significant increase in the SMBP content at 2-7 $\mathrm{cm}$ depth and the SMBC content at 7-12 cm depth, the SMBN content at $0-2 \mathrm{~cm}$ and $7-12 \mathrm{~cm}$ decreased significantly. These changes led to a significant increase in the SMBC:SMBN and SMBC:SMBP ratios at $0-2 \mathrm{~cm}$ and $7-12 \mathrm{~cm}$ depths, also causing a decrease in SMBN:SMBP at 2-7 cm and 7-12 cm depths (Fig. 2). Three-way ANOVA showed that, in addition to the soil depth, vegetation as an environmental factor significantly affected the SMBC content and its stoichiometry (Table 2). Further, warming also had a significant effect on SMBN and its stoichiometry. The cross-effect of vegetation $\times$ warming $\times$ soil depth significantly affected the soil microbial biomass and its stoichiometry (Table 2).

\subsection{Soil ecoenzyme activity and ecoenzymatic stoichiometry}

Compared with the unwarmed plots, long-term warming significantly decreased the AP activity in shrubland only at 7-12 cm depth, but did not have a significant effect on the activity of other enzymes in any plots (Fig. 3). The environmental factors of vegetation and soil depth significantly affected $\mathrm{C}$ - and $\mathrm{N}$-acquiring enzyme activities, whereas vegetation $\times$ warming $\times$ soil depth significantly affected $\mathrm{N}$ acquiring enzyme activity (Table 2). Regarding the different soil layers, we observed that the soil ecoenzyme activity of the topsoil sample was significantly higher than that of the bottom soil (Fig. 4). As regards enzymatic stoichiometry, long-term warming led to a significant increase in $\ln (N A G+L A P): \ln (A P)$ only at 7-12 cm depth in shrubland (Fig. 4). Compared with warming and soil depth, vegetation had the most significant effect on $\ln (B G): \ln (A P)$ and $\ln (N A G+L A P): \ln (A P)$, explaining $79.53 \%$ and $73.52 \%$ variability, respectively (Table 2 ). Vegetation $\times$ soil depth and vegetation $\times$ warming $\times$ soil depth significantly affected $\ln (B G): \ln (N A G+L A P)$, explaining $50.92 \%$ and $21.94 \%$ variability, respectively (Table 2 ).

\subsection{Vector analysis of stoichiometry}

Change in the vector analysis of stoichiometry (Fig. 4) shows that long-term warming did not have a significant effect on the vector length and angle at the same soil depth, with the vector angle of all samples being greater than $45^{\circ}$. Warming was not found an important environmental factor in the vector analysis of stoichiometry, as vegetation and soil depth were responsible for $33.61 \%$ and $20.42 \%$, respectively, of the variability in vector length, and vegetation was responsible for $80.72 \%$ of 


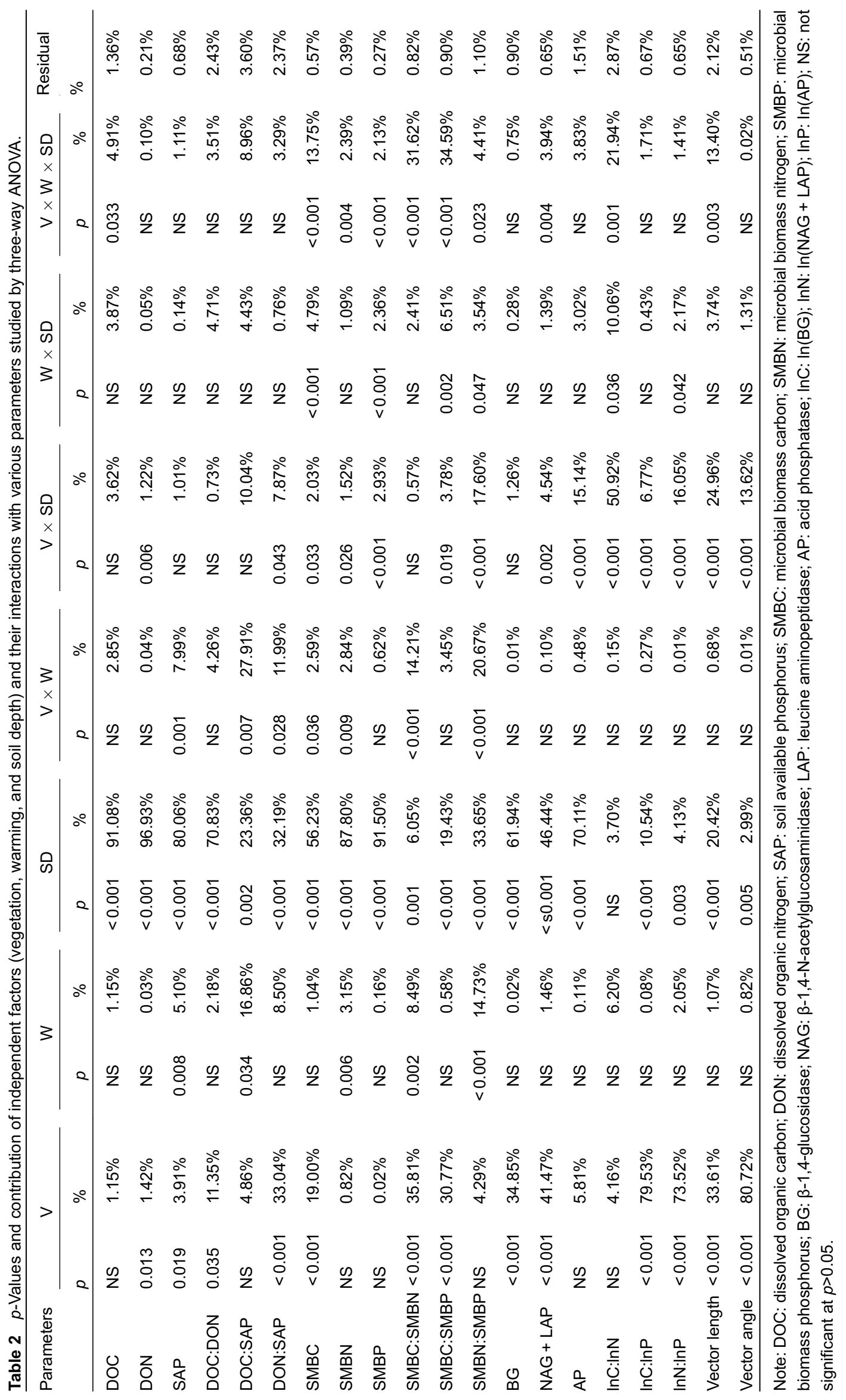



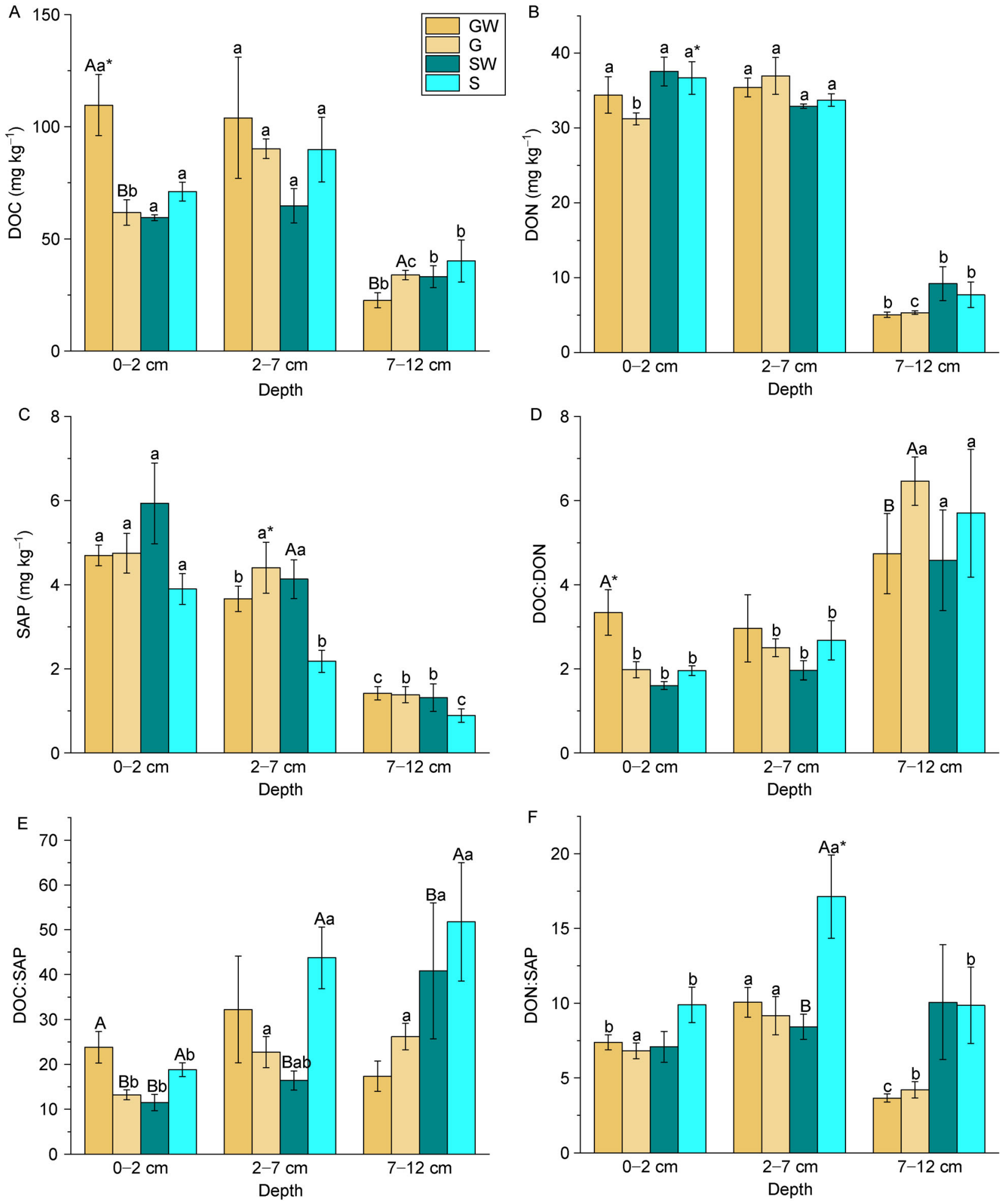

Fig. 1 Effects of long-term warming on available nutrients in soil and their stoichiometry. (A) Effect on DOC, (B) Effect on DON, (C) Effect on SAP, (D) Effect on DOC:DON, (E) Effect on DOC:SAP, (F) Effect on DON:SAP. Error bars represent the standard error. Capital letters above the bars indicate that the average values of different treatments (warming and unwarming) under the same soil depth and vegetation differ significantly $(p<0.05)$. Different lowercase letters indicate that the average values of different soil depths under the same treatment and vegetation differ significantly $(p<0.05) .{ }^{*}$ indicates that the average values of different types of vegetation plots under the same soil depth and treatment differ significantly $(p<0.05)$. 

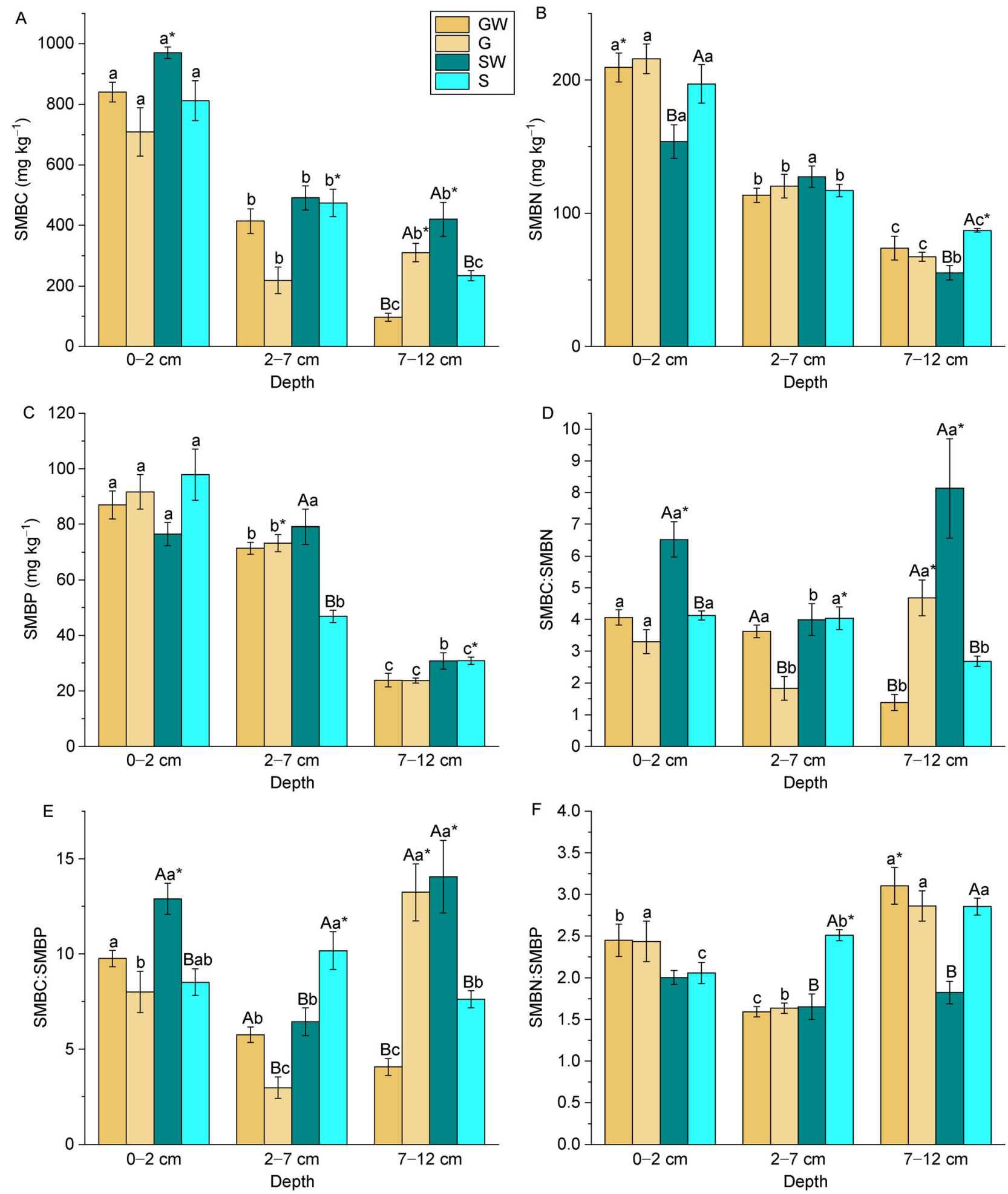

Fig. 2 Effects of long-term warming on soil microbial biomass. (A) Effect on microbial biomass $C$ (SMBC), (B) Effect on microbial biomass $N$ (SMBN), (C) Effect on microbial biomass P (SMBP), (D) Effect on SMBC:SMBN, (E) Effect on SMBC:SMBP, (F) Effect on SMBN:SMBP. Error bars represent the standard error. Capital letters above the bars indicate that the average values of different treatments (warming and unwarming) under the same soil depth and vegetation differ significantly $(p<0.05)$. Different lowercase letters indicate that the average values of different soil depths under the same treatment and vegetation differ significantly $(p<0.05)$. * indicates that the average values of different types of vegetation plots under the same soil depth and treatment differ significantly $(p<0.05)$. 

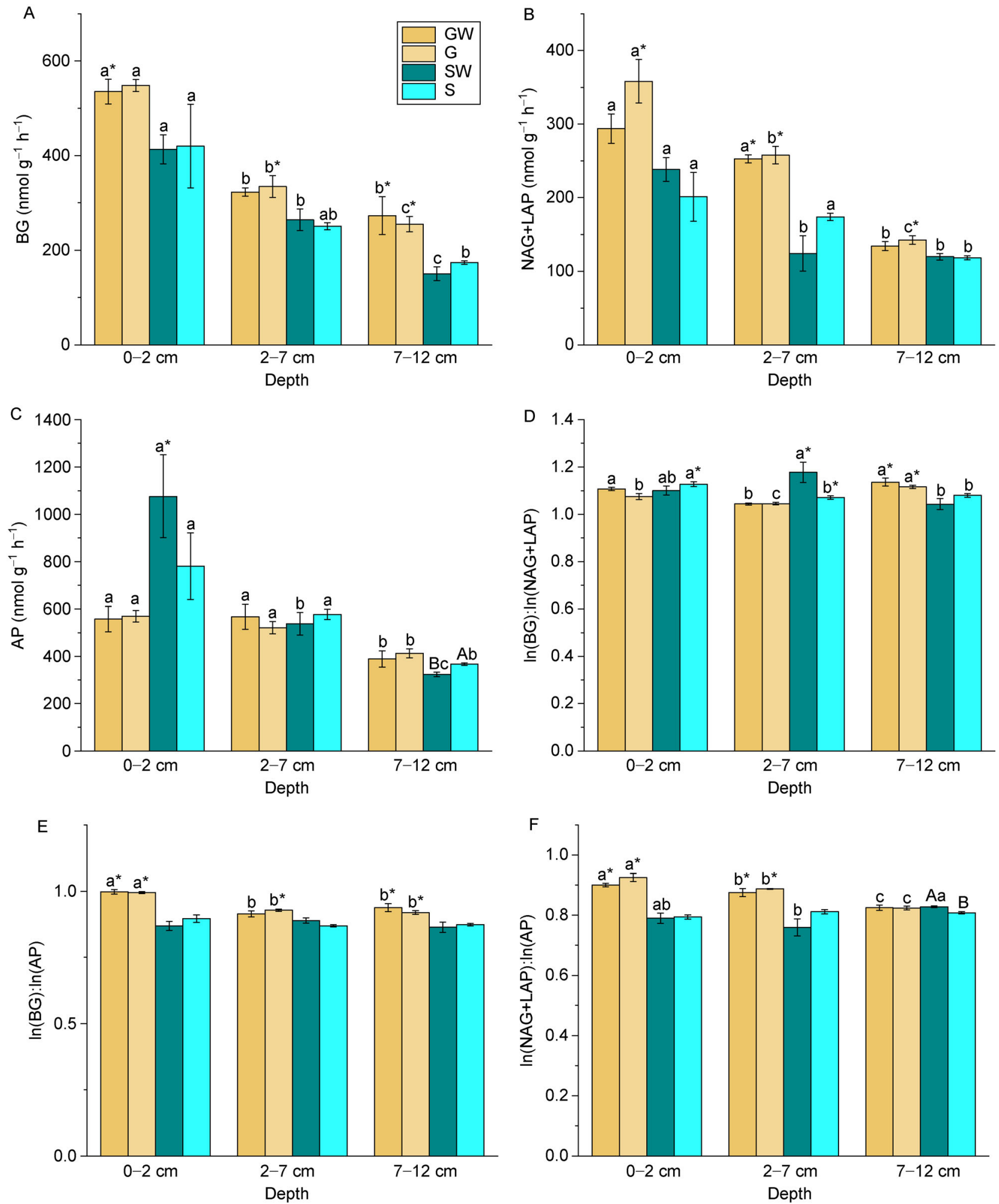

Fig. 3 Effects of long-term warming on ecoenzymatic stoichiometry. (A) Effect on the activity of BG, (B) Effect on the activity of (NAG + LAP), (C) Effect on AP, (D) Effect on $\ln (B G): \ln (N A G+L A P),(E)$ Effect on $\ln (B G): \ln (A P),(F)$ Effect on $\ln (N A G+L A P): \ln (A P)$. Error bars represent the standard error. Capital letters above the bars indicate that the average values of different treatments (warming and unwarming) under the same soil depth and vegetation differ significantly $(p<0.05)$. Different lowercase letters indicate that the average values of different soil depths under the same treatment and vegetation differ significantly $(p<0.05) .{ }^{*}$ indicates that the average values of different types of vegetation plots under the same soil depth and treatment differ significantly $(p<0.05)$. 

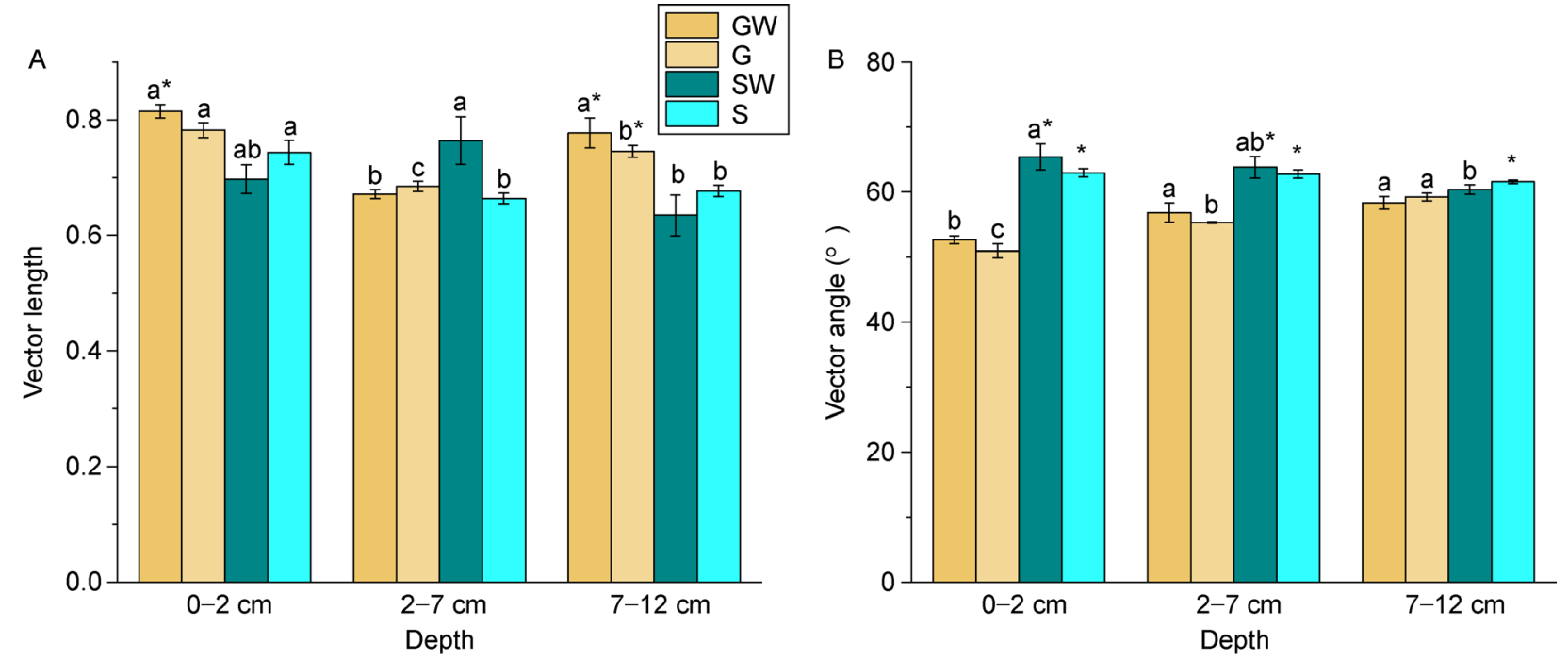

Fig. 4 Effects of long-term warming on the vector analysis of stoichiometry. (A) Effect on vector length, (B) Effect on vector angle. Error bars represent standard error. The capital letters above the bars indicate that the average values of different treatments (warming and unwarming) under the same soil depth and vegetation are significantly different $(p<0.05)$; different lowercase letters indicate the average values of different soil depths under the same treatment and vegetation are significant differences $(p<0.05)$ and * indicate the average values of different types of vegetation plots under the same soil depth and treatment were significant differences $(p<0.05)$.

the variability in vector angle. Vector length was affected significantly by the cross-effect of vegetation $\times$ warming $\times$ soil depth, but the vector angle was not affected (Table 2).

\subsection{Stratification ratio of microbial nutrient limitation}

After long-term warming, the SR1 of $\ln (B G): \ln (N A G+L A P)$ and vector length in shrubland decreased significantly, and the SR2 of the vector angle in shrubland increased significantly (Table 3). However, the comparison between the different treatments on the same soil layer suggested that long-term warming did not have a significant impact on these indicators (Figs. 3, 4).

3.6 Relationships among environmental factors and microbial nutrient limitation

Spearman correlation analysis showed that soil ecoenzyme activity was significantly and positively correlated with soil available nutrients and microbial biomass, but enzyme activity was negatively correlated with DOC:DON and DOC:SAP (Fig. 5). The $\ln (B G): \ln (A P)$ and vector length were correlated

Table 3 Soil stratification ratios of microbial nutrient limitation in two plots

\begin{tabular}{|c|c|c|c|c|c|}
\hline Stratification ratios & Parameters & GW & G & SW & $\mathrm{S}$ \\
\hline \multirow[t]{5}{*}{ SR1 } & $\ln (B G): \ln (N A G+L A P)$ & $1.06 \pm 0.008$ & $1.03 \pm 0.016$ & $0.94 \pm 0.023 \mathrm{~B}$ & $1.05 \pm 0.005 \mathrm{~A}$ \\
\hline & $\ln (B G): \ln (A P)$ & $1.09 \pm 0.016$ & $1.07 \pm 0.007$ & $0.98 \pm 0.026$ & $1.03 \pm 0.018$ \\
\hline & $\ln (N A G+L A P): \ln (A P)$ & $1.03 \pm 0.019$ & $1.04 \pm 0.015$ & $1.05 \pm 0.04$ & $0.98 \pm 0.014$ \\
\hline & Vector length & $1.21 \pm 0.018$ & $1.14 \pm 0.03$ & $0.92 \pm 0.036 \mathrm{~B}$ & $1.12 \pm 0.025 \mathrm{~A}$ \\
\hline & Vector angle & $0.93 \pm 0.025$ & $0.92 \pm 0.018$ & $1.03 \pm 0.047$ & $1.00 \pm 0.016$ \\
\hline \multirow[t]{5}{*}{ SR2 } & $\ln (B G): \ln (N A G+L A P)$ & $0.98 \pm 0.016$ & $0.96 \pm 0.016$ & $1.06 \pm 0.03$ & $1.04 \pm 0.013$ \\
\hline & $\ln (B G): \ln (A P)$ & $1.06 \pm 0.017$ & $1.08 \pm 0.008$ & $1.01 \pm 0.007$ & $1.03 \pm 0.018$ \\
\hline & $\ln (N A G+L A P): \ln (A P)$ & $1.09 \pm 0.009$ & $1.12 \pm 0.017$ & $0.95 \pm 0.021$ & $0.98 \pm 0.006$ \\
\hline & Vector length & $1.05 \pm 0.036$ & $1.05 \pm 0.03$ & $1.11 \pm 0.066$ & $1.1 \pm 0.037$ \\
\hline & Vector angle & $0.9 \pm 0.012$ & $0.86 \pm 0.017$ & $1.08 \pm 0.023 \mathrm{~A}$ & $1.02 \pm 0.011 \mathrm{~B}$ \\
\hline
\end{tabular}

Note: Different capital letters in the same row indicate significant differences between different treatments in the same plot at $p<0.05$. No comparison was made between grass plots and shrub plots. SR 1 is $0-2 \mathrm{~cm}: 2-7 \mathrm{~cm}$, and SR2 is $0-2 \mathrm{~cm}: 7-12 \mathrm{~cm}$. 
positively with microbial biomass but correlated negatively with the stoichiometry of the soil available nutrients (Fig. 5).

\section{Discussion}

\subsection{Effects of long-term warming on soil ecoenzyme activities}

We found that long-term warming did not significantly affect the enzyme activity of the soil samples at all depths in the grassland and shrubland (Figs. 3, 5, Table 2). This result is inconsistent with our hypothesis but is similar to previous research results, in which a small increase found in the soil temperature did not cause a significant change in hydrolase activity (Xiao et al., 2018; Meng et al., 2019). In our experiment, the four enzymes involved were hydrolases, which mainly degrade unstable substrates in soil (Davidson and Janssens, 2006). When the soil is stimulated by warming, soil microbes preferentially consume unstable and easily hydrolyzed substrates over the short-term (Bradford et al., 2008; Fissore et al., 2008). However, after long-term warming treatment, warming-induced declines in easily hydrolyzable nutrient pools could lead to microbial starvation. The main reason for microbial starvation is that continuous long-term warming will lead to continuous consumption of unstable substrates in the soil, which will change the proportion of soil stubborn substrates, and these phenomena will require the soil microbial community to change their secreted enzymes to adapt to these changes (Meng et al., 2019). Under such circumstances, soil microbial communities start utilizing previously inaccessible stubborn substrates to fuel their metabolic activities (Craine et al., 2010). In our result, the soil organic carbon (SOC) reduces after long-term warming (Table S1), but there is no significant change in soil available nutrients (Fig. 1), which means microbes decompose part of the stubborn substrate during the warming process. Along with the change in available substrates, soil microbes regulate their own physiologic activities; consequently, the effect of long-term temperature change on the availability of substrates affects the secretion of their own enzymes (Machmuller et al., 2016).

Spearman correlation analysis showed that soil ecoenzyme activity was very positively correlated with the available soil nutrient content and microbial biomass (Fig. 5). This result supported our inference that soil microbes could adjust the secretion of enzymes according to their own needs and the availability of the surrounding nutrients. If microbes were forced to use stubborn substrates, the biological process required them to secrete oxidases instead of hydrolases (Majuakim and Kitayama, 2013). Therefore, the change in the use of microbial substrates after long-term warming limited the positive response of hydrolase activity to warming.

\subsection{Effect of long-term warming on microbial nutrient limitation}

Recently, potential exoenzyme activity has often been used to infer microbial nutrient limitations in the soil (Tapia-Torres et al., 2015; Cui et al., 2018; Zhang et al., 2019; Wang et al., 2020; Wu et al., 2021). Enzymes are important tools for microbes to obtain nutrients, and also are the rate-limiting steps of microbes' catalytic decomposition and nutrient mineralization (Sinsabaugh et al., 2008; Sinsabaugh et al.,

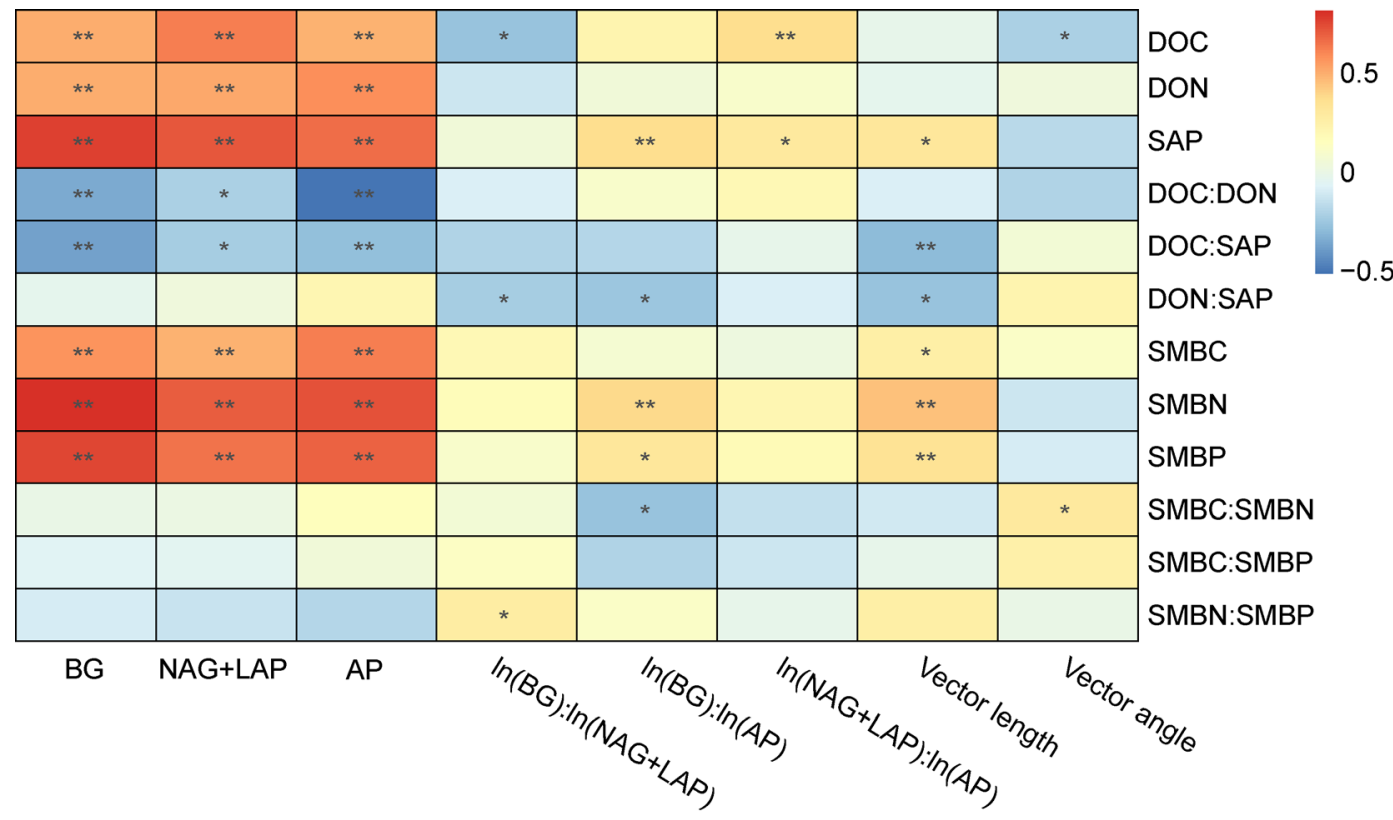

Fig. 5 Spearman correlation between soil properties, their stoichiometry, the soil ecoenzyme activity and the indicators of the microbial nutrient limitation. DOC: dissolved organic carbon; DON: dissolved organic nitrogen; SAP: soil available phosphorus; SMBC: microbial

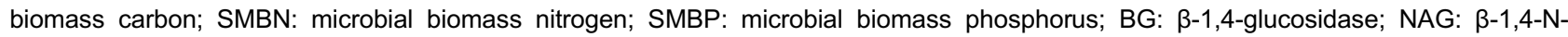
acetylglucosaminidase; LAP: leucine aminopeptidase; AP: acid phosphatase. ${ }^{*}: p<0.05$; ${ }^{*}: p<0.01$. 
2009; Theuerl and Buscot, 2010; Sinsabaugh and Shah, 2012; Tian et al., 2020). Therefore, the production of enzymes for different nutrients reflects the metabolic and stoichiometric requirements of soil microorganisms (Sinsabaugh and Moorhead 1994; Sinsabaugh et al., 2008). The high resourceacquiring enzyme activity indicates the nutrient limitation of this resource, and the ratio of different resource-acquiring enzymes reflects the relative nutrient availability and nutrient factors that restrict microorganisms (Sinsabaugh et al., 1993; Sinsabaugh and Moorhead, 1994). Since the stoichiometry of microbial biomass is relatively stable in the entire ecosystem, when the ecosystem environment changes, the investment of microbes in obtaining $\mathrm{C}, \mathrm{N}$, and $\mathrm{P}$ should be different to maintain the original steady-state of the microorganisms (Cleveland and Liptzin, 2007; Sinsabaugh et al., 2014). Therefore, this method which is based on enzyme activity and their stoichiometry has been widely applied in different soil types across several ecosystems and used to infer microbial nutrient limitation in soil (Waring et al., 2014; TapiaTorres et al., 2015; Cui et al., 2018; Zhang et al., 2019; Wang et al., 2020; Wu et al., 2021). However, this method still has certain limitations. It can indicate the resource requirements of the total soil microbial community to a certain extent, but cannot specifically indicate the limiting factors for the growth of the bacterial or fungal communities in the soil (Rosinger et al., 2019). Therefore, the enzyme cannot fully reflect the in situ activity of soil microbes, and the discussion on enzyme stoichiometry should focus onthe resource requirements of the soil microbes.

Soil ecoenzymatic stoichiometry indicates a biogeochemical balance between the availability of environmental substrates and the resource allocation of microbes (Sinsabaugh and Shah, 2011; Sinsabaugh and Shah, 2012). It has been reported that the ratio of enzyme activity that obtains $C$, $\mathrm{N}$, and $\mathrm{P}$ is approximately $1: 1: 1$ at global and regional scales (Sinsabaugh et al., 2008; Sinsabaugh et al., 2009). However, in our study, the $\mathrm{C}: \mathrm{N}: \mathrm{P}$ enzyme collection ratio $[\ln (\mathrm{BG})$ : $\ln (L A P+N A G): \ln (A P)]$ at all depths in the plots deviated from 1:1:1 (Table S2). This result suggested that the ecoenzymatic stoichiometry of alpine meadows was not at steady-state but depended on the nutrient requirements of organisms in the current ecosystem and on the availability of these nutrients (Peng and Wang, 2016).

The present study showed that the vector angles of all plots were greater than $45^{\circ}$ (Fig. 4), indicating that all plots were subjected to $\mathrm{P}$-limitation and that this limitation did not change significantly after long-term warming. The soil ecoenzymatic stoichiometry did not change significantly after long-term warming treatment, which also confirmed that, in our study, warming did not significantly change microbial nutrient limitation (Fig. 4, Table 2). This finding is inconsistent with our previous assumptions, and the reason could be that soil microbes have adapted to environmental changes after longterm warming. The temperature increase may induce its adaptation to the environment change through ecological and evolutionary changes in the microbial community, and reduce the temperature sensitivity of extracellular enzymes (Allison et al. 2010; Machmuller et al., 2016). In the study of soil microbial respiration, the increase in respiration rate under soil warming will return to its pre-warming value within a few years, and this phenomenon is called "thermal adaptation" (Giasson et al., 2013; Romero-Olivares et al., 2017). At present, thermal adaptation is not only observed in soil microbial respiration, but similar phenomena of thermal adaptation or thermal acclimation can be found in soil microbial biomass, soil microbial structure, and soil enzyme sensitivity (Wei et al., 2014; Machmuller et al., 2016; Xu and Yuan, 2017; Dacal et al., 2019; Guo et al., 2020). All these phenomena imply that, compared with the significant response of microbial activity to short-term warming found in previous studies (Gong et al., 2019; Zheng et al., 2020), the effect of long-term warming on microbial communities could be a gradual adaptation. Bradford (2013) proposed that such thermal adaptation is observed in soil microbial respiration and growth, as the result of universal evolutionary trade-offs between the structure and function of both enzymes and membranes. And, other researchers have suggested that the thermal adaptation of soil microorganisms may be due to the acclimation of soil microbes (Bradford et al., 2010; Crowther and Bradford, 2013; Tucker et al., 2013), shifts in microbial community composition (Luo et al., 2014; Treseder et al., 2016), the evolutionary adaptation of microbes (Romero-Olivares et al., 2015), or depletion of labile C (Bradford et al., 2008; Eliasson et al., 2005). Any combination of these mechanisms can affect the response of soil activity to temperature changes, but the specific explanation remains inconclusive.

Deltedesco et al. (2020) showed that the indirect effect of climate change on microbes was higher than its direct effect, implying that the effect of long-term experimental warming on microbes was primarily the response of microbes to their own environmental changes after warming. In our experiments, warming played a role in promoting the growth of plants on two types of plots, increasing the above-ground biomass (Table S3). After long-term warming treatment, plant growth significantly increased, causing an increase in plant litter, root exudates, and root turnover. These carbon inputs from plants to the soil are beneficial for the development of microbes (Ganjurjav et al., 2016; Wang et al., 2017). However, with the development of plant and microbial communities, competition between plants and microbes could occur because of resource limitations. Plant growth would accelerate the transfer of nutrients to the plants, causing restriction of microbe growth under long-term warming conditions (Wang et al., 2017). At the same time, the long-term warming environment would accelerate the consumption of easily hydrolyzed substrates (Bradford et al., 2008; Curiel Yuste et al., 2010). This would also require the microbes to invest more energy in decomposing stubborn substances, instead of in the growth of their own community (Davidson and Janssens, 2006; Craine et al., 2010). Both competition and 
decomposition of stubborn substrates would reduce the investment of microbes in their own growth (Manzoni et al., 2012). The thermal adaptation of microorganisms and the fierce competition brought about by plant growth restrict the activities of microorganisms. In addition, our results showed that insignificant changes in the soil available nutrient pools (especially $\mathrm{N}$ and $\mathrm{P}$ ) in the experimental plots eventually led to relatively stable microbial nutrient limitation.

Under different soil depths, the SR1 of vector length and the SR2 of vector angle in shrubland showed a significant change (Table 3); however, warming did not have a significant effect on the vector analysis at any soil depth (Fig. 4). In the sample plots of the two vegetation types, the distribution of soil nutrients and microbial biomass is correlated highly with soil depth. This characteristic also induced a significant effect on microbial nutrient limitation from soil depth, but the crosseffect of warming and soil depth did not have a significant effect on microbial nutrient limitation (Table 2).

Our experimental design and sampling method ensured that all soil samples of $0-12 \mathrm{~cm}$ depth received the warming effect of OTCs, with the deepest sample being not as warm as the surface soil owing to soil barrier effect; however, all soil layers were subjected to temperature increases. This resulted in changes in the use of substrates and the thermal adaptation of microbes in the deep soil (Davidson and Janssens, 2006; $\mathrm{Xu}$ and Yuan, 2017). Perhaps the deep soil is not synchronized with the surface soil, but after 21 years of long-term warming, experimental observations could not clearly capture any significant difference in the response to warming between the bottom soil and the topsoil.

\section{Conclusions}

Long-term warming caused microbes to produce thermal adaptation phenomena and changed the availability of substrate for the microbial community, resulting in an insignificant effect on the hydrolase activity and the microbial nutrient limitation indicated by hydrolytic enzymes. Between different soil layers, the stratification ratio of microbial nutrient limitation did not be observed a significant change after warming. Our research aids further understanding of the effects of long-term warming on soil ecological enzyme activity and microbial nutrient limitation. However, our research still has limitations, and it is difficult to find strong evidence to explain the phenomenon of thermal adaptation in microbial activities. Accordingly, further research is required to explain the mechanism.

\section{Acknowledgments}

This work was supported financially by the National Natural Science Foundation of China (31672475), Qinghai Provincial Key Laboratory of Restoration Ecology in Cold Regions, North-west Institute of Plateau Biology (2020-KF- 04) and Qinghai Innovation Platform Construction Project (2021-ZJ-Y010).

\section{Conflict of interest statement}

This article has no conflict of interest and has not been published in other journals.

\section{Electronic supplementary material}

Supplementary material is available in the online version of this article at https://doi.org/10.1007/s42832-021-0116-0 and is accessible for authorized users.

\section{References}

Bai, T., Tao, J., Li, Z., Shu, M., Yan, X., Wang, P., Ye, C., Guo, H., Wang, Y., Hu, S., 2019. Different microbial responses in top- and sub-soils to elevated temperature and substrate addition in a semiarid grassland on the Loess Plateau. European Journal of Soil Science 70, 1025-1036.

Barta, J., Slajsova, P., Tahovska, K., Picek, T., Santruckova, H., 2014. Different temperature sensitivity and kinetics of soil enzymes indicate seasonal shifts in $\mathrm{C}, \mathrm{N}$ and $\mathrm{P}$ nutrient stoichiometry in acid forest soil. Biogeochemistry 117, 525-537.

Bradford, M.A., 2013. Thermal adaptation of decomposer communities in warming soils. Frontiers in Microbiology 4, 4.

Bradford, M.A., Davies, C.A., Frey, S.D., Maddox, T.R., Melillo, J.M., Mohan, J.E., Reynolds, J.F., Treseder, K.K., Wallenstein, M.D., 2008. Thermal adaptation of soil microbial respiration to elevated temperature. Ecology Letters 11, 1316-1327.

Bradford, M.A., Watts, B.W., Davies, C.A., 2010. Thermal adaptation of heterotrophic soil respiration in laboratory microcosms. Global Change Biology 16, 1576-1588.

Brookes, P.C., Landman, A., Pruden, G., Jenkinson, D.S., 1985. Chloroform fumigation and the release of soil nitrogen: $A$ rapid direct extraction method to measure microbial biomass nitrogen in soil. Soil Biology \& Biochemistry 17, 837-842.

Caldwell, B.A., 2005. Enzyme activities as a component of soil biodiversity: A review. Pedobiologia 49, 637-644.

Chen, H., Zheng, M., Mao, Q., Xiao, K., Wang, K., Li, D., 2019. Cropland conversion changes the status of microbial resource limitation in degraded karst soil. Geoderma 352, 197-203.

Chen, W., Zhou, H., Wu, Y., Wang, J., Zhao, Z., Li, Y., Qiao, L., Chen, K., Liu, G., Xue, S., 2020. Direct and indirect influences of longterm fertilization on microbial carbon and nitrogen cycles in an alpine grassland. Soil Biology \& Biochemistry 149, 149.

Cleveland, C.C., Liptzin, D., 2007. C: N: P stoichiometry in soil: is there a "Redfield ratio" for the microbial biomass? Biogeochemistry 85, 235-252.

Craine, J.M., Fierer, N., McLauchlan, K.K., 2010. Widespread coupling between the rate and temperature sensitivity of organic matter decay. Nature Geoscience 3, 854-857.

Crowther, T.W., Bradford, M.A., 2013. Thermal acclimation in widespread heterotrophic soil microbes. Ecology Letters 16, 469-477.

Cui, Y., Fang, L., Guo, X., Wang, X., Zhang, Y., Li, P., Zhang, X., 2018. Ecoenzymatic stoichiometry and microbial nutrient limitation in rhizosphere soil in the arid area of the northern Loess Plateau, 
China. Soil Biology \& Biochemistry 116, 11-21.

Curiel Yuste, J., Ma, S., Baldocchi, D.D., 2010. Plant-soil interactions and acclimation to temperature of microbial-mediated soil respiration may affect predictions of soil $\mathrm{CO}_{2}$ efflux. Biogeochemistry 98 , 127-138.

Dacal, M., Bradford, M.A., Plaza, C., Maestre, F.T., Garcia-Palacios, P., 2019. Soil microbial respiration adapts to ambient temperature in global drylands. Nature Ecology \& Evolution 3, 232-238.

Davidson, E.A., Janssens, I.A., 2006. Temperature sensitivity of soil carbon decomposition and feedbacks to climate change. Nature 440, 165-173.

Deltedesco, E., Keiblinger, K.M., Piepho, H.P., Antonielli, L., Poetsch, E.M., Zechmeister-Boltenstern, S., Gorfer, M., 2020. Soil microbial community structure and function mainly respond to indirect effects in a multifactorial climate manipulation experiment. Soil Biology \& Biochemistry 142, 142.

Eliasson, P.E., McMurtrie, R.E., Pepper, D.A., Stromgren, M., Linder, S., Agren, G.I., 2005. The response of heterotrophic $\mathrm{CO}_{2}$ flux to soil warming. Global Change Biology 11, 167-181.

Fierer, N., Schimel, J.P., Holden, P.A., 2003. Variations in microbial community composition through two soil depth profiles. Soil Biology \& Biochemistry 35, 167-176.

Fissore, C., Giardina, C.P., Kolka, R.K., Trettin, C.C., King, G.M., Jurgensen, M.F., Barton, C.D., McDowell, S.D., 2008. Temperature and vegetation effects on soil organic carbon quality along a forested mean annual temperature gradient in North America. Global Change Biology 14, 193-205.

Ganjurjav, H., Gao, Q., Gornish, E.S., Schwartz, M.W., Liang, Y., Cao, X., Zhang, W., Zhang, Y., Li, W., Wan, Y., Li, Y., Danjiu, L., Guo, H., Lin, E., 2016. Differential response of alpine steppe and alpine meadow to climate warming in the central Qinghai-Tibetan Plateau. Agricultural and Forest Meteorology 223, 233-240.

Giasson, M.A., Ellison, A.M., Bowden, R.D., Crill, P.M., Davidson, E. A., Drake, J.E., Frey, S.D., Hadley, J.L., Lavine, M., Melillo, J.M., Munger, J.W., Nadelhoffer, K.J., Nicoll, L., Ollinger, S.V., Savage, K.E., Steudler, P.A., Tang, J., Varner, R.K., Wofsy, S.C., Foster, D. R., Finzi, A.C., 2013. Soil respiration in a northeastern US temperate forest: a 22-year synthesis. Ecosphere 4, art140.

Gong, S.W., Zhang, T., Guo, J.X., 2019. Warming and Nitrogen Addition Change the Soil and Soil Microbial Biomass C:N:P Stoichiometry of a Meadow Steppe. International Journal of Environmental Research and Public Health 16, 2705.

Gruber, N., Galloway, J.N., 2008. An Earth-system perspective of the global nitrogen cycle. Nature 451, 293-296.

Guo, X., Gao, Q., Yuan, M., Wang, G., Zhou, X., Feng, J., Shi, Z., Hale, L., Wu, L., Zhou, A., Tian, R., Liu, F., Wu, B., Chen, L., Jung, C.G., Niu, S., Li, D., Xu, X., Jiang, L., Escalas, A., Wu, L., He, Z., Van Nostrand, J.D., Ning, D., Liu, X., Yang, Y., Schuur, E.A.G., Konstantinidis, K.T., Cole, J.R., Penton, C.R., Luo, Y., Tiedje, J.M., Zhou, J., 2020. Gene-informed decomposition model predicts lower soil carbon loss due to persistent microbial adaptation to warming. Nature Communications 11, 4897.

IPCC, 2018. Special Report on Global Warming of $1.5^{\circ} \mathrm{C}$. Cambridge University Press, UK.

Kalbitz, K., Schmerwitz, J., Schwesig, D., Matzner, E., 2003. Biodegradation of soil-derived dissolved organic matter as related to its properties. Geoderma 113, 273-291.

Liu, H., Yang, X., Liang, C., Li, Y., Qiao, L., Ai, Z., Xue, S., Liu, G., 2019. Interactive effects of microplastics and glyphosate on the dynamics of soil dissolved organic matter in a Chinese loess soil. Catena 182, 182.

Luo, C., Rodriguez-R, L.M., Johnston, E.R., Wu, L., Cheng, L., Xue, K., Tu, Q., Deng, Y., He, Z., Shi, J.Z., Yuan, M.M., Sherry, R.A., Li, D., Luo, Y., Schuur, E.A.G., Chain, P., Tiedje, J.M., Zhou, J., Konstantinidis, K.T., 2014. Soil Microbial Community Responses to a Decade of Warming as Revealed by Comparative Metagenomics. Applied and Environmental Microbiology 80, 1777-1786.

Machmuller, M.B., Mohan, J.E., Minucci, J.M., Phillips, C.A., Wurzburger, N., 2016. Season, but not experimental warming, affects the activity and temperature sensitivity of extracellular enzymes. Biogeochemistry 131, 255-265.

Majuakim, L., Kitayama, K., 2013. Influence of polyphenols on soil nitrogen mineralization through the formation of bound protein in tropical montane forests of Mount Kinabalu, Borneo. Soil Biology \& Biochemistry 57, 14-21.

Manzoni, S., Schimel, J.P., Porporato, A., 2012. Responses of soil microbial communities to water stress: results from a metaanalysis. Ecology 93, 930-938.

Meng, C., Tian, D., Zeng, H., Li, Z., Chen, H.Y.H., Niu, S., 2019. Global meta-analysis on the responses of soil extracellular enzyme activities to warming. Science of the Total Environment 705, 135992.

Moorhead, D.L., Rinkes, Z.L., Sinsabaugh, R.L., Weintraub, M.N., 2013. Dynamic relationships between microbial biomass, respiration, inorganic nutrients and enzyme activities: informing enzymebased decomposition models. Frontiers in Microbiology 4, 4.

Moorhead, D.L., Sinsabaugh, R.L., Hill, B.H., Weintraub, M.N., 2016. Vector analysis of ecoenzyme activities reveal constraints on coupled C, N and P dynamics. Soil Biology \& Biochemistry 93, 1-7.

Olsen, S.R., Sommers, L.E., 1982. Phosphorous. In: Page, A.L., Miller, R.H., Keeney, D.R. (Eds.), Methods of Soil Analysis, Part 2, Chemical and Microbial Properties. Agronomy Monograph, vol. 9. Agronomy Society of America, pp. 403e430 (Madison, Wisconsin).

Peng, X., Wang, W., 2016. Stoichiometry of soil extracellular enzyme activity along a climatic transect in temperate grasslands of northern China. Soil Biology \& Biochemistry 98, 74-84.

Romero-Olivares, A.L., Allison, S.D., Treseder, K.K., 2017. Soil microbes and their response to experimental warming over time: A meta-analysis of field studies. Soil Biology \& Biochemistry 107, 32-40.

Romero-Olivares, A.L., Taylor, J.W., Treseder, K.K., 2015. Neurospora discreta as a model to assess adaptation of soil fungi to warming. BMC Evolutionary Biology 15, 15.

Rosinger, C., Rousk, J., Sanden, H., 2019. Can enzymatic stoichiometry be used to determine growth-limiting nutrients for microorganisms? - A critical assessment in two subtropical soils. Soil Biology \& Biochemistry 128, 115-126.

Rui, Y., Wang, Y., Chen, C., Zhou, X., Wang, S., Xu, Z., Duan, J., Kang, X., Lu, S., Luo, C., 2012. Warming and grazing increase mineralization of organic $P$ in an alpine meadow ecosystem of Qinghai-Tibet Plateau, China. Plant and Soil 357, 73-87.

Rustad, L.E., Campbell, J.L., Marion, G.M., Norby, R.J., Mitchell, M.J., 
Hartley, A.E., Cornelissen, J.H.C., Gurevitch, J., Gcte, N., 2001. A meta-analysis of the response of soil respiration, net nitrogen mineralization, and aboveground plant growth to experimental ecosystem warming. Oecologia 126, 543-562.

Saiya-Cork, K.R., Sinsabaugh, R.L., Zak, D.R., 2002. The effects of long term nitrogen deposition on extracellular enzyme activity in an Acer saccharum forest soil. Soil Biology \& Biochemistry 34, 1309 1315

Schindlbacher, A., Schnecker, J., Takriti, M., Borken, W., Wanek, W., 2015. Microbial physiology and soil $\mathrm{CO}_{2}$ efflux after 9 years of soil warming in a temperate forest - no indications for thermal adaptations. Global Change Biology 21, 4265-4277.

Sinsabaugh, R.L., Antibus, R.K., Linkins, A.E., McClaugherty, C.A., Rayburn, L., Repert, D., Weiland, T., 1993. Wood decompositionnitrogen and phosphorus dynamics in relation to extracellular enzyme-activity. Ecology 74, 1586-1593.

Sinsabaugh, R.L., Belnap, J., Findlay, S.G., Shah, J.J.F., Hill, B.H., Kuehn, K.A., Kuske, C.R., Litvak, M.E., Martinez, N.G., Moorhead, D.L., Warnock, D.D., 2014. Extracellular enzyme kinetics scale with resource availability. Biogeochemistry 121, 287-304.

Sinsabaugh, R.L., Hill, B.H., Follstad Shah, J.J., 2009. Ecoenzymatic stoichiometry of microbial organic nutrient acquisition in soil and sediment. Nature 462, 795-798

Sinsabaugh, R.L., Lauber, C.L., Weintraub, M.N., Ahmed, B., Allison, S.D., Crenshaw, C., Contosta, A.R., Cusack, D., Frey, S., Gallo, M. E., Gartner, T.B., Hobbie, S.E., Holland, K., Keeler, B.L., Powers, J. S., Stursova, M., Takacs-Vesbach, C., Waldrop, M.P., Wallenstein, M.D., Zak, D.R., Zeglin, L.H., 2008. Stoichiometry of soil enzyme activity at global scale. Ecology Letters 11, 1252-1264.

Sinsabaugh, R.L., Moorhead, D.L., 1994. Resource-allocation to extracellular enzyme-production - a model for nitrogen and phosphorus control of litter decomposition. Soil Biology \& Biochemistry 26, 1305-1311.

Sinsabaugh, R.L., Shah, J.J.F., 2011. Ecoenzymatic stoichiometry of recalcitrant organic matter decomposition: the growth rate hypothesis in reverse. Biogeochemistry 102, 31-43.

Sinsabaugh, R.L., Shah, J.J.F., 2012. Ecoenzymatic Stoichiometry and Ecological Theory. In: D.J. Futuyma (Ed.), Annual Review of Ecology, Evolution, and Systematics, Vol 43. Annual Review of Ecology Evolution and Systematics, pp. 313-343.

Sinsabaugh, R.L., Shah, J.J.F., Hill, B.H., Elonen, C.M., 2012. Ecoenzymatic stoichiometry of stream sediments with comparison to terrestrial soils. Biogeochemistry 111, 455-467.

Steinweg, J.M., Dukes, J.S., Wallenstein, M.D., 2012. Modeling the effects of temperature and moisture on soil enzyme activity: Linking laboratory assays to continuous field data. Soil Biology \& Biochemistry 55, 85-92.

Tapia-Torres, Y., Elser, J.J., Souza, V., García-Oliva, F., 2015. Ecoenzymatic stoichiometry at the extremes: How microbes cope in an ultra-oligotrophic desert soil. Soil Biology \& Biochemistry $87,34-42$.

Theuerl, S., Buscot, F., 2010. Laccases: toward disentangling their diversity and functions in relation to soil organic matter cycling. Biology and Fertility of Soils 46, 215-225.

Tian, P., Razavi, B.S., Zhang, X., Wang, Q., Blagodatskaya, E., 2020. Microbial growth and enzyme kinetics in rhizosphere hotspots are modulated by soil organics and nutrient availability. Soil Biology \& Biochemistry 141, 141.

Treseder, K.K., Marusenko, Y., Romero-Olivares, A.L., Maltz, M.R., 2016. Experimental warming alters potential function of the fungal community in boreal forest. Global Change Biology 22, 33953404.

Tucker, C.L., Bell, J., Pendall, E., Ogle, K., 2013. Does declining carbon-use efficiency explain thermal acclimation of soil respiration with warming? Global Change Biology 19, 252-263.

Vance, E.D., Brookes, P.C., Jenkinson, D.S., 1987. An extraction method for measuring soil microbial biomass C. Soil Biology \& Biochemistry 19, 703-707.

Veres, Z., Kotroczo, Z., Fekete, I., Toth, J.A., Lajtha, K., Townsend, K., Tothmeresz, B., 2015. Soil extracellular enzyme activities are sensitive indicators of detrital inputs and carbon availability. Applied Soil Ecology 92, 18-23.

Wang, C., Wang, G., Wang, Y., Zi, H., Lerdau, M., Liu, W., 2017. Effects of long-term experimental warming on plant community properties and soil microbial community composition in an alpine meadow. Israel Journal of Ecology \& Evolution 63, 85-96.

Wang, J., Wang, X., Liu, G., Wang, G., Wu, Y., Zhang, C., 2020. Fencing as an effective approach for restoration of alpine meadows: Evidence from nutrient limitation of soil microbes. Geoderma 363, 363.

Waring, B.G., Weintraub, S.R., Sinsabaugh, R.L., 2014. Ecoenzymatic stoichiometry of microbial nutrient acquisition in tropical soils. Biogeochemistry 117, 101-113.

Wei, H., Guenet, B., Vicca, S., Nunan, N., AbdElgawad, H., Pouteau, V., Shen, W., Janssens, I.A., 2014. Thermal acclimation of organic matter decomposition in an artificial forest soil is related to shifts in microbial community structure. Soil Biology \& Biochemistry 71, 112.

Wu, Y., Chen, W., Li, Q., Guo, Z., Li, Y., Zhao, Z., Zhai, J., Liu, G., Xue, S., 2021. Ecoenzymatic stoichiometry and nutrient limitation under a natural secondary succession of vegetation on the Loess Plateau, China. Land Degradation \& Development 32, 399- 409.

Xiao, W., Chen, X., Jing, X., Zhu, B., 2018. A meta-analysis of soil extracellular enzyme activities in response to global change. Soil Biology \& Biochemistry 123, 21-32.

Xu, W., Yuan, W., 2017. Responses of microbial biomass carbon and nitrogen to experimental warming: A meta-analysis. Soil Biology \& Biochemistry 115, 265-274.

Xue, S., Yang, X., Liu, G., Gai, L., Zhang, C., Ritsema, C.J., Geissen, V., 2017. Effects of elevated $\mathrm{CO}_{2}$ and drought on the microbial biomass and enzymatic activities in the rhizospheres of two grass species in Chinese loess soil. Geoderma 286, 25-34.

Yu, P., Tang, X., Liu, S., Liu, W., Zhang, A., 2020. Short Term Effects of Revegetation on Labile Carbon and Available Nutrients of Sodic Soils in Northeast China. Land (Basel) 9, 10.

Zhang, B., Chen, S.Y., Zhang, J.F., He, X.Y., Liu, W.J., Zhao, Q., Zhao, L., Tian, C.J., 2015. Depth-related responses of soil microbial communities toexperimental warming in an alpine meadow on the Qinghai-Tibet Plateau. European Journal of Soil Science 66, 496504.

Zhang, J., Ai, Z., Liang, C., Wang, G., Liu, G., Xue, S., 2019. How microbes cope with short-term $\mathrm{N}$ addition in a Pinus tabuliformis 
forest-ecological stoichiometry. Geoderma 337, 630-640.

Zheng, H.F., Liu, Y., Chen, Y.M., Zhang, J., Li, H.J., Wang, L.F., Chen, Q.M., 2020. Short-term warming shifts microbial nutrient limitation without changing the bacterial community structure in an alpine timberline of the eastern Tibetan Plateau. Geoderma 360, 360.

Zheng, W., Zhou, J.c., Lin, W.s., Zheng, Y., Li, C., Li, X.f., Ji, Y.h., Yang, Z.j., 2019. Effects of soil warming on soil microbial extracellular enzyme activities with different depths in a young Chinese fir (Cunninghamia lanceolata) plantation of subtropics. Chinese
Journal of Applied Ecology 30, 832-840.

Zhou, X., Chen, C., Wang, Y., Xu, Z., Han, H., Li, L., Wan, S., 2013. Warming and increased precipitation have differential effects on soil extracellular enzyme activities in a temperate grassland. Science of the Total Environment 444, 552-558.

Zi, H.B., Hu, L., Wang, C.T., Wang, G.X., Wu, P.F., Lerdau, M., Ade, L. J., 2018. Responses of soil bacterial community and enzyme activity to experimental warming of an alpine meadow. European Journal of Soil Science 69, 429-438. 